\title{
Integrasi Etnomatematika Dalam Kurikulum Matematika Sekolah
}

\author{
Alfonsa M. Abi ${ }^{1)}$ \\ 1) Prodi Pendidikan Matematika STKIP SOE, NTT, Indonesia \\ E-mail:fonsa_fan@yahoo.com
}

\begin{abstract}
Abstrak. Etnomatematika merupakan matematika yang diterapkan oleh kelompok budaya tertentu. Itu berarti etnomatematika bukan sekedar bicara tentang etnis atau suku. Karena pengajaran matematika di sekolah dan matematika yang ditemukan anak dalam kehidupan sehari-hari sangat berbeda, maka pembelajaran matematika sangat perlu memberikan muatan/menjembatani antara matematika dalam dunia sehari-hari yang berbasis pada budaya lokal dengan matematika sekolah. Melihat kurikulum 2013 yang menanamkan pemikiran ilmiah dan pendidikan karakter, menjadi rasional untuk mengintegrasikan etnomatematika dan pembelajaran matematika. Tulisan ini membahas kemungkinan pengintegrasian etnomatematika ke dalam kurikulum matematika dan model pembelajaran yang mendukung pembelajarannya.
\end{abstract}

Kata Kunci: Integrasi, Etnomatematika, Matematika Sekolah, CTL

\section{PENDAHULUAN}

Contextual Teaching and Learning (CTL) atau yang dikenal dengan pembelajaran kontekstual merupakan sebuah model pembelajaran yang mengaitkan materi dengan situasi dunia nyata peserta didik. Model pembelajaran ini mendorong peserta didik mendefinisikan hubungan antara pengetahuan yang telah dimiliki dan penerapannya dalam kehidupan mereka sebagai anggota masyarakat. Model ini sudah digaungkan sejak lama dan terbukti mengatasi kesulitan peserta didik dalam belajar serta menciptakan peserta didik yang kreatif, inovatif dan kritis seperti penelitian yang dilakukan oleh peneliti-peneliti sebelumnya. Hal ini bukan berarti model pembelajaran yang lain tidak bagus. Tetapi jika pembelajaran disesuaikan dengan kehidupan peserta didik tentulah tidak akan terlalu sulit disesuaikan terutama pada pembelajaran matematika yang mana memiliki tingkat keabstrakan yang tinggi. Konsep abstrak dan hanya ada dibayang-bayang peserta didik mampu ditransformasikan ke dalam kehidupan mereka. Ini merupakan salah satu motivasi bahwa matematika memiliki kegunaan yang besar dalam kehidupan dan merupakan bagian dari kehidupan mereka. Dengan demikian, matematika tidak perlu ditakuti.
Hiebert \& Capenter (dalam Alfonsa, 2015) mengingatkan kepada semua pihak bahwa pengajaran matematika di sekolah dan matematika yang ditemukan anak dalam kehidupan sehari-hari sangat berbeda. Bentuk-bentuk aktivitas, artefak maupun ide yang dijalani oleh peserta didik telah membudaya. Mereka tidak perlu membayangkan apa yang tidak pernah dialami, cukuplah mengerti dan memahami karena mereka telah melakukan dan melihatnya setiap hari bahkan terlibat dalam mencipta. Inilah yang disebut kebudayaan dan beberapa kalangan pada era 80-an mulai melakukan penelitian dan pengembangan dalam pembelajaran matematika yang mereka sebut dengan etnomatematika. Etnomatematika mulai dintegrasikan ke dalam kurikulum matematika sekolah dengan asumsi awal untuk melestarikan nilai dari kebudayaan yang semakin hilang ditelan perkembangan zaman.

Penelitian yang dilakukan oleh D'Ambrosio (1986) menjadi titik tolak dari penyadaran peran etnomatematika pada pembelajaran. Argumentasi ini didukung pula oleh Bishop (198.) hingga menyebar ke daerah Afrika (e.g. [1], [2]), Jepang dan Tionghoa [3]. Melihat keragaman budaya yang ada di Indonesia maka [4], [5] dan [6] melakukan penelitian dan pengembangan bahan ajar berintegrasi etnomatematika dan 
menyimpulkan bahwa peran etnomatematika sangatlah penting sebagai sarana untuk memotivasi, menstimulasi peserta didik, dapat mengatasi kejenuhan dan memberikan nuansa baru pada pembelajaran matematika. Karena etnomatematika sudah dikenal oleh peserta didik sehingga dalam mengajak peserta didik untuk mengidentifikasi dan mengaitkan bagian dari budaya yang sudah mereka kenal ke dalam suatu materi matematika dengan panduan yang diberikan guru akan lebih mudah.

Alfonsa (2015), telah mengeksplorasi sebagian budaya masyarakat suku Amanuban dan memperoleh relasi yang sangat dekat antara matematika dan budaya yang dimiliki. Walaupun di kabupaten Timor Tengah Selatan memiliki 3 (tiga) suku besar yaitu Mollo, Amanuban dan Amanatun tidak terdapat perbedaan yang jauh antara kebudayaan yang dimiliki ketiga suku ini. Hal yang paling mencolok hanyalah dialek.

Berdasarkan uraian diatas, yang menjadi latar belakang dari kajian ini adalah bagaimana peran etnomatematika dalam pembelajaran matematika khususnya pada daerah kabupaten Timor Tengah Selatan. Kajian literatur ini diharapkan memberikan dampak yang luas baik bagi pihak sekolah dalam pengembangan bahan ajar dan implementasinya dalam pembelajaran maupun kepada masyarakat sebagai usaha sadar untuk melestarikan budaya yang dimiliki.

\section{PEMBAHASAN}

James dan James dalam [7] menjelaskan matematika sebagai ilmu tentang logika mengenai bentuk, susunan, besaran, konsep-konsep yang berhubungan satu dengan yang lainnya dengan jumlah yang banyak dan terbagi dalam tiga bidang yaitu aljabar, analisis, dan geometri. Ada pula kelompok lain yang beranggapan bahwa matematika adalah ilmu yang dikembangkan untuk matematika itu sendiri. Ilmu adalah untuk ilmu, dan matematika adalah ilmu yang dikembangkan untuk kepentingan sendiri. Matematika adalah ilmu tentang struktur yang bersifat deduktif atau aksiomatik, akurat, abstrak, dan ketat.

Objek matematika adalah abstrak, pembahasannya deduktif, harus logis,berjenjang, serta melibatkan operasi. Tetapi uniknya, matematika adalah ibu dan sekaligus pelayan sehingga dapat dipakai dalam ilmu yang lain serta terintegrasi dalam kehidupan sehari-hari. Inilah yang membuat matematika adalah ilmu yang sangat berguna. Namun, di lain pihak dalam mempelajari matematika terdapat banyak kesulitan dan keluhan. Diantaranya adalah matematika adalah ilmu yang abstrak, sulit dipahami dan masih menjadi momok di kalangan peserta didik maupun guru.

Salah satu langkah untuk mengurangi pandangan negatif terhadap matematika adalah dengan pembelajaran kontekstual atau membawa dunia nyata peserta didik ke dalam pembelajaran itu sendiri. Hal ini sejalan dengan etnomatematika. Secara etimologis, etnomatematika berasal dari kata ethno dan matematic. Ethno berarti etnis dan matematic berarti matematika. Menurut [1], etnomatematika adalah matematika yang diterapkan oleh kelompok budaya tertentu, kelompok buruh/petani, anak-anak dari masyarakat kelas tertentu, kelas-kelas profesional, dan lain sebagainya. Ini berarti etnomatematika bukan sekedar bicara tentang etnis atau suku. Hiebert \& Capenter (1992) mengingatkan kepada semua pihak bahwa pengajaran matematika di sekolah dan matematika yang ditemukan anak dalam kehidupan sehari-hari sangat berbeda. Oleh sebab itu pembelajaran matematika sangat perlu memberikan muatan/menjembatani matematika dengan kehidupan sehari-hari yang berbasis pada budaya lokal dengan matematika sekolah. Dengan asumsi bahwa etnomatematika yang diangkat sudah dikenal dan dapat membantu peserta didik dalam belajar matematika.

Model pembelajaran yang mendukung pembelajaran berbasis etnomatematika adalah model Contextual Teaching and Learning (CTL). CTL merupakan konsep pembelajaran yang menekankan pada keterkaitan antara materi pembelajaran dengan dunia kehidupan peserta didik secara nyata, sehingga mereka mampu menghubungkan dan menerapkan kompetensi hasil belajar dalam kehidupan sehari-hari. [8] mengungkapkan bahwa dalam CTL terdapat 8 (delapan) komponen yang harus dilakukan dalam proses pembelajaran yaitu (1) membuat 


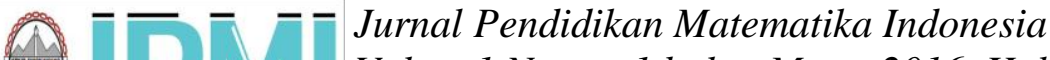

keterkaitan yang bermakna; (2) melakukan pekerjaan yang berarti; (3) melakukan pembelajaran yang diatur sendiri; (4) bekerja sama; (5) berpikir kritis dan kreatif; (6) membantu individu untuk tumbuh dan berkembang; (7) mencapai standar yang tinggi; serta (8) menggunakan penilaian autentik. Peserta didik akan belajar secara bermakna seperti yang dikemukan teori belajar Ausubel dalam [7] karena model CTL menekankan keterlibatan peserta didik secara penuh untuk dapat menemukan materi yang dipelajari dan menghubungkannya dengan situasi kehidupan nyata sehingga mendorong peserta didik untuk menerapkannya dalam kehidupan.

CTL mendukung pendekatan saintifik pada kurikulum 2013. Dikarenakan pembelajaran model CTL dimulai dengan menkonstruk masalah, kemudian bertanya, menemukan, adanya aktivitas masyarakat belajar (dalam hal ini peserta didik), membuat model penyelesaian, adanya kegiatan refleksi, dan terakhir adalah penilaian hasil belajar. Kegiatan ini mengindikasikan bahwa peserta didik berpikir dan bertindak secara ilmiah. Langkahlangkah pembelajaran model CTL dijabarkan sebagai berikut:

a. Pertama, peserta didik didorong untuk mengemukakan pengetahuan awal tentang konsep yang dibahas. Bila perlu peserta didik di pancing dengan memberikan pertanyaan yang problematik tentang kehidupan sehari-hari.

b. Kedua, peserta didik diberi kesempatan untuk menyelidiki dan menemukan konsep melalui pengumpulan, pengorganisasian, perinterpretasian data dalam sebuah kegiatan yang telah dirancang oleh guru. Kemudian secara berkelompok peserta didik berdiskusi tentang masalah yang bahas.

c. Ketiga, peserta didik menyampaikan, membuat model dan membuat rangkuman serta ringkasan hasil pekerjaan bimbingan guru.

d. Keempat, peserta didik dapat membuat keputusan menggunakan pengetahuan dan keterampilan, berbagai informasi dan gagasan, mengajukan pertanyaan lanjutan, mengajukan saran baik secara individu maupun secara kelompok yang berhubungan dengan pemecahan masalah.
Gagne dalam [7] mengklasifikasikan objek matematika ke dalam objek langsung dan objek tak langsung. Objek langsung mencakup fakta, konsep, prinsip, dan keterampilan. Objek tak langsung mencakup kemampuan berpikir logis, kemampuan memecahkan masalah, bersikap positif, tekun, teliti, kerja sama, dan jujur, yang memiliki keterkaitan dengan pembentukan karakter peserta didik. Pendapat Gagne juga didukung oleh Dienes yang mengungkapkan bahwa setiap konsep (atau prinsip) matematika dapat dipahami dengan tepat hanya jika mulamula disajikan melalui berbagai representasi konkret/fisik. Dienes menggunakan istilah konsep untuk menunjuk suatu struktur matematika, suatu definisi tentang konsep yang jauh lebih luas daripada definisi Gagne.

Penggunaan benda-benda konkrit yang ada di sekitar peserta didik dalam mendukung pembelajaran matematika bukanlah hal yang mudah dalam pelaksanaannya, namun bukanlah hal baru dalam dunia pendidikan terutama dalam membelajarkan matematika yang dianggap abstrak dan banyak simbol. Sifat keabstrakan matematika ini memberi kesempatan kepada guru dalam memilih strategi, model dan media dalam mengajarkan matematika agar tujuan pembelajaran yang dimaksud dapat tercapai. Hal ini sejalan dengan apa yang diungkapkan oleh [4], [5], dan [6] dalam penelitian mereka. Mereka mencoba mengungkapkan kebudayaan yang dimiliki masing-masing daerah yang dapat diimplementasikan ke dalam pembelajaran matematika yang mereka sebut etnomatematika.

Pembelajaran model CTL melibatkan lingkungan sekitar siswa. [9] menyimpulkan bahwa CTL dapat meningkatkan kualitas pembelajaran matematika karena peserta didik mengalami langsung materi atau konsep yang diajarkan. Materi pelajaran ditemukan sendiri oleh peserta didik, bukan hasil pemberian dari orang lain. Kelas bukanlah tempat untuk mencatat atau menerima informasi dari guru, akan tetapi kelas digunakan untuk saling membelajarkan. Hal ini dibenarkan [10] yang membuktikan bahwa penerapan pembelajaran kontekstual bermedia objek nyata meningkatkan hasil belajar peserta didik secara signifikan. Oleh karena itu, CTL 
mampu meningkatkan pemahaman konsep dan berpikir kritis peserta didik. [11] mengemukakan bahwa kemampuan berpikir matematis peserta didik yang menggunakan pendekatan kontekstual lebih baik. Selain pemahaman konsep dan berpikir kritis peserta didik meningkat, CTL juga mampu meningkatkan kemampuan komunikasi mereka. Hal ini disampaikan oleh [12] bahwa peningkatan kemampuan komunikasi matematik peserta didik yang memperoleh pembelajaran dengan pendekatan kontekstual lebih baik daripada yang memperoleh pembelajaran konvensional. Dengan model pembelajaran CTL, pengintegrasian budaya ke dalam kurikulum pengajaran menjadi salah satu solusi yang murah dan menyenangkan. Hal inilah yang mengakibatkan munculnya ilmu etnomatematika.

Menurut [1], etnomatematika adalah matematika yang diterapkan oleh kelompok budaya tertentu, kelompok buruh/petani, anakanak dari masyarakat kelas tertentu, kelas-kelas profesional, dan lain sebagainya. Ini berarti etnomatematika bukan sekedar bicara tentang etnis atau suku. Pembelajaran matematika sangat perlu memberikan muatan/menjembatani antara matematika dalam dunia sehari-hari yang berbasis pada budaya lokal dengan matematika sekolah. Jadi dapat diartikan bahwa etnomatematika adalah integrasi budaya dalam pembelajaran matematika atau dengan kata lain matematika yang berunsur budaya. Budaya yang diangkat tergantung di mana dan kepada siapa matematika itu diajarkan. Dengan asumsi bahwa etnomatematika yang diangkat sudah dikenal dan dapat membantu peserta didik dalam belajar matematika.

Zaenuri, dkk (2014) menjelaskan bahwa berbagai bentuk etnomatematika pada budaya masyarakat berelasi dengan konsep-konsep matematika, seperti aturan sinus dan aturan cosinus, luas dan keliling persegi panjang, persegi, jajar genjang, dan belah ketupat, luas permukaan dan volum kubus, prisma, limas, dan tabung, serta himpunan sehingga dapat diintegrasikan dalam pembelajaran matematika, baik di jenjang pendidikan dasar (SMP) dan menengah (SMA/SMK). Penelitian lainnya mendukung bahwa etnomatematika dapat diintegrasikan ke dalam pembelajaran dan tentu saja etnomatematika yang digunakan disesuaikan dengan konsep matematika yang terkandung di dalam bentuk etnomatematika itu sendiri. [4] menyatakan penerapan etnomatematika sebagai sarana untuk memotivasi, menstimulasi peserta didik, dapat mengatasi kejenuhan dan memberikan nuansa baru pada pembelajaran matematika. Karena Etnomatematika sudah dikenal oleh peserta didik sehingga dalam mengajak peserta didik untuk mengidentifikasi dan mengaitkan bagian dari budaya yang sudah mereka kenal ke dalam suatu materi matematika dengan panduan yang diberikan guru akan lebih mudah.

Danoebroto (2012) menggunakan model pembelajaran matematika berbasis pendidikan multikultural yang dikembangkan dari lima dimensi pendidikan multikultural James Banks yaitu integrasi budaya dalam konten matematika, konstruksi pengetahuan matematika melalui konteks dan pemahaman budaya, kesetaraan pedagogik, mengurangi prejudice dan memberdayakan kultur sekolah yang kondusif. Pembelajaran matematika berbasis pendidikan multikultural bertujuan untuk mengoptimalkan prestasi belajar matematika sekaligus menumbuhkan kesadaran, kesepahaman, toleransi, saling pengertian dan semangat kebangsaan individu peserta didik sebagai bagian dari masyarakat yang multikultur.

Terdapat bentuk-bentuk hasil budaya masyarakat yang memuat konsep matematika dan dibangun menjadi sebuah pendekatan dalam pembelajaran. Pembelajaran ini yang kemudian disebut sebagai pembelajaran berbasis budaya. Tentu saja setiap bentuk etnomatematika disesuaikan dengan konsep matematika yang sepadan dan tidak menghambat peserta didik dalam mempelajari matematika. Oleh karena itu, pembelajaran perlu dikemas sebaik mungkin.

Alfonsa (2015) menyimpulkan bahwa konsep matematika telah dimiliki dan dihidupi masyarakat sejak lama. Hal ini terealisasi dari bentuk etnomatematika suku Amanuban yang memuat banyak konsep-konsep matematika terutama dalam bidang geometri dan aljabar. Konsep geometri yang terekam dalam kebudayaan masyarakat suku Amanuban yaitu lingkaran, persegi, persegi panjang, belah ketupat, kerucut, 
limas, prisma, segi banyak, balok, tabung dan kubus. Selain luas permukaan, konsep volume pun dapat dianalisis dari bentuk-bentuk etnomatematika yang ada. Operasi bilangan bulat baik itu penjumlahan, pengurangan, perkalian dan pembagian dapat anda temukan dalam permainan tradisional yang dimiliki oleh masyarakat. Konsep peluang dan barisan aritmatika serta konsep yang lain perlu dianalisis secara mendalam. Hubungan bentuk etnomatematika dengan konsep matematika disajikan pada tabel 1 .

TABEL 1

\section{RELASI PADA TIAP TINGKATAN}

\begin{tabular}{|c|c|}
\hline Konsep Matematika & Bentuk Etnomatematika \\
\hline Peluang & $\begin{array}{l}\text { Gerakan tari Bonet, pilihan } \\
\text { warna dan motif, campuran } \\
\text { jagung bose }\end{array}$ \\
\hline $\begin{array}{l}\text { Panjang garis } \quad \begin{array}{r}\text { singgung } \\
\text { lingkaran, luas \& busur } \\
\text { lingkaran }\end{array} \\
\end{array}$ & $\begin{array}{l}\text { Tambur, sisir (kil noni), destar, } \\
\text { gula merah }\end{array}$ \\
\hline Tabung & $\begin{array}{l}\text { Tempat kapur (kal ao) dan ok } \\
\text { tuke, bentuk bakul dan taka }\end{array}$ \\
\hline Kecepatan & $\begin{array}{l}\text { Aturan permainan faela dan } \\
\text { huila beba }\end{array}$ \\
\hline Kerucut & $\begin{array}{l}\text { Bentuk gasing } \quad \& \text { bentuk } \\
\text { pengukus ubi }\end{array}$ \\
\hline $\begin{array}{l}\text { Jaring-jaring kubus dan luas } \\
\text { daerah }\end{array}$ & $\begin{array}{l}\text { Bentuk daerah permainan } \\
\text { sikidoka }\end{array}$ \\
\hline Phytagoras & Aturan main oto \\
\hline Operasi bilangan bulat & $\begin{array}{l}\text { Aturan permainan kuti kelereng } \\
\& \text { kayu do'i }\end{array}$ \\
\hline Satuan waktu \& panjang & $\begin{array}{l}\text { Jangka waktu pengolahan lahan, } \\
\text { hasil tenun }\end{array}$ \\
\hline $\begin{array}{l}\text { Penjumlahan dan perkalian; } \\
\text { perbandingan }\end{array}$ & Kegiatan panen \\
\hline Persegi panjang & $\begin{array}{l}\text { Bentuk hasil tenunan \& } \\
\text { anyaman tikar, ikat Pinggang } \\
\text { (fut noni) dan aluk, bentuk kue } \\
\text { lemet }\end{array}$ \\
\hline Luas belah ketupat & Motif buna \\
\hline Barisan aritmatika & Susunan motif dari muti \\
\hline $\begin{array}{l}\text { Luas permukaan segienam } \\
\text { beraturan }\end{array}$ & Bentuk nyiru \\
\hline Luas limas segienam & Bentuk tobe \\
\hline Luas belah ketupat & Motif anyaman \\
\hline Luas permukaan prisma & Oko \\
\hline Balok & Ketupat \\
\hline
\end{tabular}

\section{KESIMPULAN DAN SARAN}

Etnomatematika merupakan matematika yang diterapkan oleh kelompok budaya tertentu, kelompok buruh/petani, anak-anak dari masyarakat kelas tertentu, kelas-kelas profesional, dan lain sebagainya. Ini berarti etnomatematika bukan sekedar bicara tentang etnis atau suku. Karena pengajaran matematika di sekolah dan matematika yang ditemukan anak dalam kehidupan sehari-hari sangat berbeda, maka pembelajaran matematika sangat perlu memberikan muatan/menjembatani antara matematika dalam dunia sehari-hari yang berbasis pada budaya lokal dengan matematika sekolah. Melihat kurikulum 2013 yang menanamkan pemikiran ilmiah dan pendidikan karakter, menjadi rasional untuk mengintegrasikan etnomatematika dan pembelajaran matematika. Tulisan ini membahas kemungkinan pengintegrasian etnomatematika ke dalam kurikulum matematika dan model pembelajaran yang mendukung pembelajarannya.

Walaupun semua bentuk etnomatematika secara umum dapat diintegrasikan ke dalam pembelajaran tetapi jika tidak dikemas secara baik justru akan menghambat proses belajar matematika. Untuk itu perlu diadakan penelitian lanjutan yang lebih mendalam dalam membahas konsep-konsep matematika dalam sebuah kebudayaan, adanya pengembangan bahan ajar berbasis etnomatematika yang kemudian diukur tingkat miskonsepsinya dalam pembelajaran.

\section{DAFTAR PUSTAKA}

[1] Gerdes, P. "On Ethnomathematics and the Transmission of Mathematical Knowledge In and Outside Schools in Africa South of the Sahara.'Les Sciences Hors D'occidentali Me Siecle. (5): 229-246. 1996.

[2] Lipka, J. \& Irhke, D. A. "Ethnomathematics applied to classrooms in Alaska: Math in a Cultural Context. " The Journal of Mathematics and Culture. 3 (1):8-10. 2009.

[3] Uloko, E.S. \& Imoko, B. I. "Effects of ethno mathematics teaching approach and gender on students' achievement in Locus." Journal National Association Social Humanity Education. 5 (1): 31-36. 2007.

[4] Sirate, F. S. "Implementasi Etnomatematika Dalam Pembelajaran Matematika Pada Jenjang Pendidikan Sekolah Dasar." Lentera Pendidikan. 15 (42): 41-54. 2012.

[5] Hartoyo, A. "Eksplorasi Etnomatematika Pada Budaya Masyaraka Dayak Perbatasan Indonesia-Malaysia Kabupaten Sanggau Kalbar.' Jurnal Penelitian Pendidikan. 1 (13): 14-23. 2012.

[6] Tandililing, E. "Pengembangan Pembelajaran Matematika Sekolah Dengan Pendekatan Etnomatematika Berbasis Budaya Lokal Sebagai Upaya Untuk Meningkatkan Kualitas Pembelajaran Matematika Di Sekolah.” Prosiding. Makalah dipresentasikan dalam Seminar Nasional Matematika dan Pendidikan Matematika dengan tema "Penguatan Peran Matematika dan Pendidikan Matematika untuk Indonesia yang Lebih Baik" pada tanggal 9 November 2013 di Jurusan Pendidikan Matematika FMIPA Universitas Negeri Yogyakarta. 2013.

[7] Suherman, dkk. Strategi Pembelajaran Matematika Kontemporer. Bandung: Jica. 2003.

[8] Johnson, E. B. CTL (Contextuak Teaching \& Learning). Bandung: Kaifa. 2014

[9] Yenti, I. N. "Pendekatan Kontekstual (Ctl) Dan Implikasinya Dalam Pembelajaran Matematika." Ta'dib. 2 (12): 118-125. 2009

[10]Lestari, S. "Pembelajaran Kontekstual Bermedia Objek Nyata pada Perkalian dan Pembagian untuk Meningkatkan Motivasi dan Hasi Belajar.” Jurnal Pendidikan Sains. 4 (2): 238-249. 2014. 
[11] Senjawati, E. I. "Penerapan Pendekatan Kontekstual untuk Meningkatkan Kemampuan Komunikasi Matematik Siswa SMk di Kota Cimahi." Prosiding. Makalah dipresentasikan dalam Seminar Nasional Pendidikan Matematika dengan tema " Implementasi Kurikulum 2013 Melalui Inovasi Pembelajaran Matematika untuk Menunjang Optimalnya Hardskill dan Softskill siswa” pada tanggal 27 Nopember 2014 di STKIP Siliwangi. 2014. 